\title{
Effect of Etidronic Acid and EDTA on Root Canal Dentin - An SEM Analysis
}

Research Article

Bharathi S ${ }^{1}$, Subash Sharma ${ }^{2 *}$, Adimulapu Hima Sandeep ${ }^{3}$

${ }^{1}$ Saveetha Dental College and Hospitals, Saveetha Institute of Medical and Technical Sciences, Saveetha University, Chennai, India.

${ }^{2}$ Reader, Department of Conservative Dentistry and Endodontics, Saveetha Dental College and Hospitals, Saveetha Institute of Medical and Technical Sciences, Saveetha University, Chennai, India.

${ }^{3}$ Senior Lecturer, Department of Conservative Dentistry and Endodontics, Saveetha Dental College and Hospitals, Saveetha Institute of Medical and Technical Sciences, Saveetha University, Chennai, India.

\section{Abstract}

Objective: The main objective of the study is to analyse the effect of Etidronic acid and 17\% EDTA on loss of root dentin using Scanning electron microscope.

Background: Etidronic acid and 17\% EDTA are few chelating agents, which act on the inorganic matter for complete smear layer removal.The aim of the study is to evaluate the Etidronic acid and 17\% EDTA onroot canal dentin using SEM analysis.

Materials and Methods: Single rooted extracted human tooth was taken and disinfected.The samples were decoronated using diamond disc. The samples were divided into three groups and three different irrigants (EDTA,Etidronic acid and saline) were used to irrigate the three groups separately. Root canals were enlarged till 80size $\mathrm{K}$ file and GG drill no 4 .The teeth were split into two equal longitudinal halves using chisel and mallet and then immersed in the respective irrigant for 30 mins and then viewed under Scanning Electron Microscope and scoring were given accordingly.

Results: All irrigants tested, removed smear layer effectively there was no significant difference between 17\% EDTA and 9\% Etidronic acid ( $\mathrm{p}$ value $=0.965) .9 \%$ Etidronic acid is as effective as smear layer removal as $17 \%$ EDTA.

Conclusion: $17 \%$ EDTA and $9 \%$ Etidronic acid showed almost the same score therefore $9 \%$ Etidronic acid can be used as a better alternate for $17 \%$ EDTA as desmearing agent.

Keywords: EDTA; Smear; Etidronic Acid; Chelating Agents.

\section{Introduction}

The root canal system is complex and accessory structures, such as fins, cul de sacs, and inter canal communications, are colonized by microorganisms once the tooth becomes infected $[1,2]$. The microorganisms associated with endodontic infections comprises of a complex mixture of bacterial species. It has been reported that the root canal microbiota recovered from asymptomatic teeth is different from that isolated from clinically symptomatic teeth [3]. Both aerobic and anaerobic microorganisms as well as facultative microorganisms can be found in the root canal. Endodontic disease is one, which is caused and facilitated by microbial action. The management of such disease is primarily through removal of necrotic pulp tissue and disinfection of microbes. This is done by the endodontic treatment via mechanical instrumentation and irrigation of the canal system. Irrigation is presently the best method for lubrication, destruction of microbes, the removal of tissue remnants, and dentin debris during instrumentation. The simple act of irrigation allows the flushes away loose, necrotic, contaminated materials before that they are involuntarily pushed deeper into the canal and apical tissues, compromising the periapical tissue. The success of endodontic treatment is mainly dependent on biomechanical cleaning, shaping and disinfection of the root canal system. Although, the mechanical instrumentation is an essential step in the success of root canal therapy, the generation of the smear layer is an inevitable consequence of instrumentation regardless of the type of instruments and techniques used.

*Corresponding Author:

Subash Sharma,

Reader, Department of Conservative Dentistry and Endodontics, Saveetha Dental College and Hospitals, Saveetha Institute of Medical and Technical Sciences, Saveetha University, Chennai, India.

Tel: 9884533118

E-mail: drsubashsharma@gmail.com

Received: November 05, 2020

Accepted: November 23, 2020

Published: November 26, 2020

Citation: Bharathi S, Subash Sharma, Adimulapu Hima Sandeep. Effect of Etidronic Acid and EDTA on Root Canal Dentin - An SEM Analysis. Int J Dentistry Oral Sci. 2020;S10:02:0012:63-68. doi: http://dx.doi.org/10.19070/2377-8075-SI02-0100012

Copyright: Subash Sharma 2020 . This is an open-access article distributed under the terms of the Creative Commons Attribution License, which permits unrestricted use, distribution and reproduction in any medium, provided the original author and source are credited. 
McComb and Smith [4] were first to find the smear layer on the surface of the instrumented root canal wall. Lester and Boyde [5] described the smear layer as "organic matter trapped within translocated inorganic dentin." Smear layer contains both organic and inorganic components. The smear layer has been recommended to be removed as it may be having mixture of bacteria and their by-products $[6,7]$. Since smear layer create a space between the inner wall of the root canal and the obturating materials it may block the penetration of irrigants and intracanal medicaments into the dentinal tubules and prevent the close adaptation and adherence of sealer cement onto canal walls [8-10]. Smear layer removal facilitates opening of dentinal tubules for intracanal medication action and allow better adhesion of the root canal filling material. Therefore, endodontic treatment should not be limited to the removal of pulp remnants and the widening of the root canal, but also focus on removal of smear layer [11]. Ultrasonic instruments, lasers, and irrigants have been used for chemical and mechanical debridement during root canal treatment for the smear layer removal. Irrigants are stable complexes formed because of the bond between metal ions and chelator itself (ligand) having more than one pair of free electrons. They induce changes in calcium and phosphorus ion concentration in the root canal dentin [12]. The demineralizing effect of irrigants acts simultaneously on the smear layer and the root canal dentin, resulting in collagen exposure and reduction of dentin micro hardness. Reduction in micro hardness of the most superficial layer of root canal dentin is more advantageous ( $50 \mu \mathrm{m}$ per canal wall). It can help in negotiation and facilitation of endodontic instrumentation in fine calcified canals and smear layer removal increases the penetration into the dentinal tubules to permit disinfection [13]. The continuous irrigation protocol optimizes the bond strength of a sealer to dentine [14].

Ideal Requirement of Root Canal Irrigants. It appears evident that root canal irrigants ideally should [15].

i. have a broad antimicrobial spectrum and high efficacy against anaerobic and facultative microorganisms organized in biofilms, ii. ability to completely dissolve necrotic pulp tissue remnants, iii. ability to inactivate endotoxin,

iv. ability to prevent the formation of a smear layer during instrumentation or dissolve the latter once it has formed,

$\mathrm{v}$. be systemically nontoxic when they come in contact with the vital tissues,

vi. be non-caustic to periodontal tissues,

vii. be little or no potential to cause an anaphylactic reaction.

A large number of substances have been used as root canal irrigants, including acids (citric and phosphoric), chelating agent (ethylene diaminetetraacetic acid-EDTA, HEBP), proteolytic enzymes, alkaline solutions (sodium hypochlorite, sodium hydroxide, urea, and potassium hydroxide), oxidative agents (hydrogen peroxide and Gly-Oxide), local anaesthetic solutions, Chlorhexidine Gluconate and normal saline [16]. The most widely used endodontic irrigant is $0.5 \%$ to $6.0 \%$ sodium hypochlorite $(\mathrm{NaOCl})$, because of its bactericidal activity and ability to dissolve vital and necrotic organic tissue $[17,18]$. However, $\mathrm{NaOCl}$ solutions exert no effects on inorganic components of smear layer. In recent times Chelant and acid solutions have been recommended for removing the smear layer from instrumented root canals, including ethylene diaminetetraacetic acid (EDTA), citric acid, and phosphoric acid $[19,20]$ however most of themwere found to reduce the hardness of dentin and weakenit.

\section{Ethylene diaminetetraacetic acid}

Ethylenediaminetetraacetic acid (EDTA) is the most frequently used chelator in endodontics [21]. Several studies have shown that the use of a combination of sodium hypochlorite $(2.5-5 \%)$ and EDTA (10-17\%) is particularly effective in the removal of organic and inorganic debris. EDTA is a Ca chelating agent, and therefore capable of removing smear layer. It has been found that a final flush of EDTA can open up the dentinal tubules, and thus it increases the number of lateral canals to be filled [22-24].

\section{Etidronic acid}

Etidronic acid (also known as 1-hydroxyethylidene-1,1-bisphosphonate or HEBP) is a biocompatible chelator that can be used in combination with sodium hypochlorite and have adequate calcium chelating capacity [25]. Etidronic acid (1-hydroxyethylidene-1,1 bisphosphonate or HEBP) has been investigated as a potential alternative. HEBP is nontoxic and has been systematically used to treat bone diseases [26]. Like EDTA, it has chelating property and is commonly used as an adjunct in personal care and household products such as soaps.

\section{Saline}

Normal Saline Normal saline is isotonic to the body fluids. It is universally accepted as the most common irrigating solution in all endodontic and surgical procedures. It is also found to have no side effects, even if pushed into the periapical tissues [28]. However, saline should not be the only solution to be used as an irrigant, it is preferably used in combination with or used in between irrigations with other solutions like sodium hypochlorite [29].

The present study evaluates and compares the effect of $17 \%$ EDTA, 9\% Etidronic acid, and saline in their ability to remove smear layer following root canal instrumentation on human extracted tooth using scanning electron microscope (SEM).

\section{Materials and Methods}

\section{Solution preparation}

$17 \%$ EDTA was prepared by adding $17 \mathrm{~g}$ of disodium salt of EDTA powder into $100 \mathrm{ml}$ of distilled water. 9\% of Etidronic acid was prepared by adding 9 gm of Etidronic powder into 100 $\mathrm{ml}$ of distilled water. Saline was bought from the local dental dealer. All solutions were stored at room temperature in airtight dark containers between experiments.

\section{Teeth selection and Preparation}

Ethical clearance was taken before starting the study. Fifteen freshly extracted single rooted human upper anteriors were collected. They were caries free and had single canal and mature apex. Teeth with cracks or fracture lines were eliminated after examining using loupes. Teeth with complete root formation, patent canals and without anatomic variations. Teeth having curved root, root resorption, and calcified canal were not included in the study. Buccal and proximal radiographs were taken to ensure that the 
teeth had only single canal. The teeth were cleaned of debris and soft tissue remnants and were stored in saline solution.

Teeth were randomly divided into three groups with 5 teeth in each group according to the final irrigation protocol. Prepared Samples were divided in to experimental groups:

Group 1: 17\% EDTA is used during instrumentation

Group 2: 9\% Etidronic acid is used during instrumentation Group 3: Saline is used during instrumentation

Each tooth was decorated from the Cemento-enamel junction (CEJ) by using a slow speed, water-cooled diamond disc bur to obtain uniform working length. Standard access cavities were prepared. The working length was checked with a size $10 \mathrm{~K}$-file (Dentsply Maillefer, Ballaigues, Switzerland) introduced into the root canal of each tooth up to the point until it became visible at the apex and then pulled back $1 \mathrm{~mm}$. The initial coronal preparation was done with Gates-Glidden drills (Dentsply Maillefer, Ballaigues, Switzerland) up to number 4 size. All the samples were instrumented using standardized crown down technique with sequentially sized $\mathrm{K}$ files (Dentsply-Maillefer, Ballaigues, Switzerland) is used up to size 80 . Throughout instrumentation, canals were irrigated using $2 \mathrm{ml}$ of 17\% EDTA, saline and 9\% Etidronic acid between each file. (Figure -1)
Final irrigation was done with $5 \mathrm{ml}$ of distilled water for each sample; all root canals were dried with absorbent paper points (Dentsply). Two parallel longitudinal grooves were prepared on the buccal and lingual surfaces of each root using a diamond disc withoutcutting through the root canal. Roots were then split into two halves with a chisel and mallet. For each root, the half containing the most visible part up of the apex was conserved and coded. Then the tooth was immersed into the respective irrigant for 30 minutes. The coded specimens were then mounted on metallic stubs, gold sputtered, air dried and placed in a vacuum chamber and observed. The dentinal surfaces were observed at apical thirds under SEM for the presence or absence of smear layer with a magnification of $\times 2,000$ and $\times 3000$ and visualization of the entrance to dentinal tubule After that photomicrographs were taken at x2000 and x3000 magnification at apical third (2 mm to apex) of each specimen (Figure 2 and 3).

\section{Scoring Criteria}

A teaching faculty, who was blind to the irrigation regimens employed for each group by using scores as follows, evaluated the removal of smear layer.

Score 1: Root surface without smear layer with the dentinal tu-

Figure 1. Prepared Specimens - Decoronated Tooth.

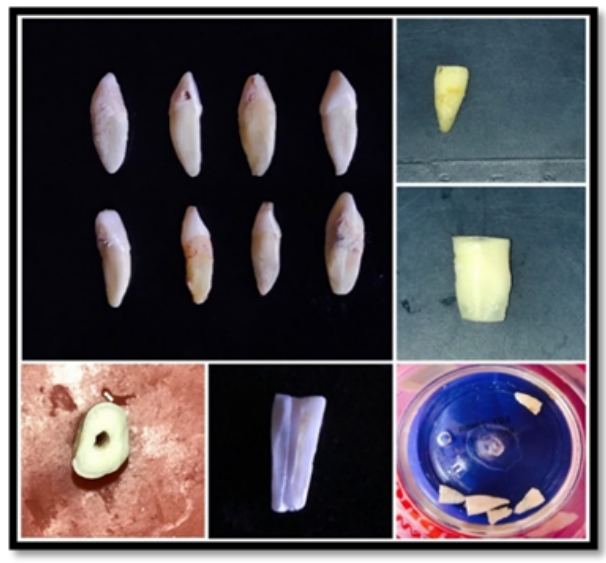

Figure 2. The Dentinal Surfaces were observed at Apical Thirds under SEM for the Presence or Absence of Smear Layer with a Magnification of X2,000.

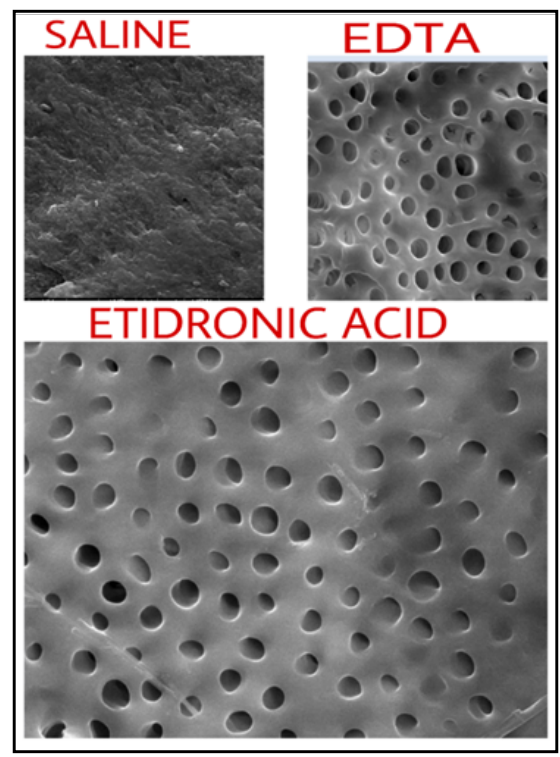


bules completely open without evidence of smear layer in the dentinal tubules.

Score 2: Root surface without smear layer with the dentinal tubules completely open, but with some evidence of smear layer in the dentinal tubules entrance.

Score 3: Root surface without smear layer with the dentinal tubules partially open.

Score 4: Root surface covered by a uniform smear layer, with evidence of dentinal tubules opening.

Score 5: Root surface covered by a uniform smear layer without evidence of dentinal tubules opening.

Score 6: Root surface covered by an irregular smear layer, with the presence of grooves and/or scattered debris.

\section{Statistical methods}

Statistical Package for Social Sciences (SPSS) version 16 was used for analysis:

1. Kruskal-Wallis analysis of variance (ANOVA) was used for comparisons

2. Mann-Whitney $U$ test was used for comparisons.

\section{Results and Discussions}

All irrigants tested, removed smear layer effectively form the apical third. 17\% EDTA (Group 1) and 9\% Etidronic Acid (Group 2) showed almost the same results. Saline (Group 2) showed the poor result (table 1 and table 2) and (Figure 4 and 5). There was no significant difference between 17\% EDTA and 9\% Etidronic acid ( $p$ value -0.965$)$ and there was significant difference between saline and Etidronic acid ( $p$ value - 0.011) (Table-3).

The purpose of irrigating a root canal is twofold, firstly to re-

Figure 3. The Dentinal Surfaces were observed at Apical Thirds under SEM for the Presence or Absence of Smear Layer with a Magnification of X2,000.

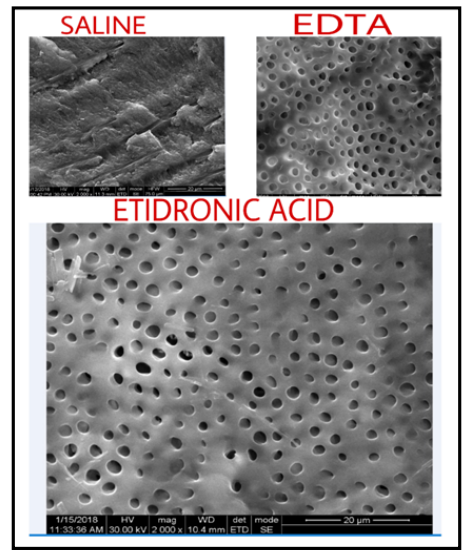

Table 1. Kruskal-Wallis Test.

\begin{tabular}{|c|c|c|c|}
\hline & GROUP & $\mathbf{N}$ & Mean Rank \\
\hline \multirow{4}{*}{ CONSE } & $17 \%$ EDTA & 5 & 7.9 \\
\cline { 2 - 4 } & $9 \%$ HEBP & 5 & 8.4 \\
\cline { 2 - 4 } & SALINE & 5 & 21.7 \\
\cline { 2 - 4 } & Total & 15 & \\
\hline
\end{tabular}

Table 2. Mann-Whitney Test.

\begin{tabular}{|c|c|c|c|c|}
\hline & GROUP & $\mathbf{N}$ & Mean Rank & Sum of Ranks \\
\hline \multirow{4}{*}{ CONSE } & $17 \%$ EDTA & 5 & 3.2 & 16 \\
\cline { 2 - 5 } & SALINE & 5 & 7.8 & 39 \\
\cline { 2 - 5 } & $9 \%$ HEBP & 5 & 3.3 & 16.5 \\
\cline { 2 - 5 } & Total & 15 & & \\
\hline
\end{tabular}

Figure 4. Kruskal Wallis Test.

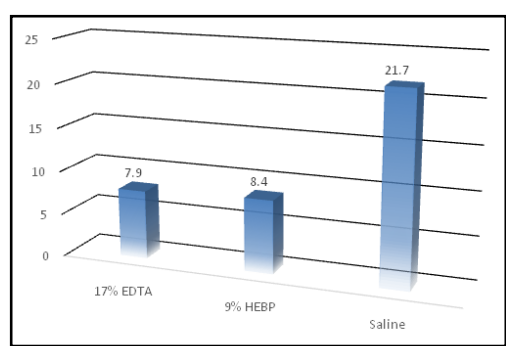


Figure 5. Mann - Whitney Test.

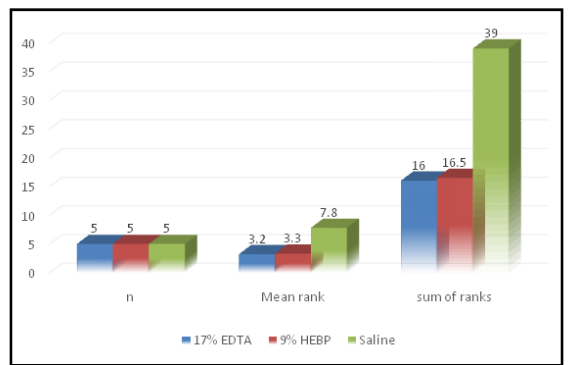

Table 3. P-value of the groups.

\begin{tabular}{|c|c|c|}
\hline Groups & p value & \\
\hline $17 \%$ EDTA $-9 \%$ HEBP & 0.965 & NS \\
\hline $9 \%$ EDTA - Saline & 0.011 & $\mathrm{~S}$ \\
\hline
\end{tabular}

move the organic component, the debris originating from pulp tissue and microorganisms, and secondly in removing the inorganic component \& the smear layer. Smear layer is composed of a superficial layer that is firmly adhered to the dentine surface, and a deep layer that is formed by smaller particles that are compacted into the dentinal tubules, making the deep layer difficult to remove. The first researchers to describe the smear layer on the surface of instrumented root canals were McComb \& Smith. They suggested that the smear layer consisted not only of dentine as in the coronal smear layer, but also the remnants of odontoblastic processes, pulp tissue and bacteria. It has been demonstrated that the smear layer itself may be infected and may protect the bacteria within the dentinal tubules; it may be prudent to remove the smear layer in teeth with infected root canals and allow disinfection of the entire root canal system. The generation of a smear layer is almost inevitable during root canal instrumentation. While a non-instrumentation technique has been described for canal preparation without smear formation, efforts rather focus on methods for its removal, such as chemical means and methods such as ultrasound and hydrodynamic disinfection for its disruption. Root canal preparation without the creation of a smear layer may be possible. A non-instrumental hydrodynamic technique may have future potential and sonically driven polymer instruments with tips of variable diameter are reported to disrupt the smear layer in a technique called hydrodynamic disinfection Current methods of smear layer removal include chemical, ultrasonic and laser techniques, none of which are totally effective or have received universal acceptance. Chemical debridement is especially needed for teeth with complex internal anatomy such as fins or other irregularities that might be missed by instrumentation [29]. Irrigating solutions used in endodontics clean the dentin surface, and may interfere with the chemical structure of dentin, changing the calcium/ phosphorus $(\mathrm{Ca} / \mathrm{P})$ ratio of the surface. The irrigation solutions might influence the physicochemical properties of human root canal dentin, including micro-hardness, permeability, solubility, wettability and roughness. In our study, 17\% EDTA, 9\% Etidronic acid, and Saline were used as irrigating solutions.

In our study straight single-rooted and single canal, maxillary anteriors were selected with root length of approximately 20-22 $\mathrm{mm}$ and curvature less than 5 degrees according to Schneider in order to avoid anatomic variation and to maintain standardization, which was confirmed using radiograph as suggested by Wu et al., [30]. 17\% EDTA, 9\% Etidronic acid, and Saline were used for the removal of smear layer. All the three irrigants removed smear layer. Nevertheless, compared to saline 17\% EDTA and Etidronic acid showed better results than saline (no significant difference between 17\% EDTA and 9\% Etidronic acid). Moreover, the mean rank between 17\% EDTA and 9\% Etidronic acid were almost same according to Kruskal-Wallis Test and MannWhitney test showing that 9\% Etidronic acid can be used as better alternate for $17 \%$ EDTA. This is in agreement with the previous study that have reported that both 17\% EDTA and 9\% Etidronic acid were equally effective in the apical third without any much statistical difference in removing smear layer [31].

Studies were done on the efficacy of removal of smear layer using $18 \%$ Etidronic acid and was found to be effective than $9 \%$ but $18 \%$ Etidronic acid caused erosive dental changes [23]. However, 7-9\% Etidronic acid can be used to prevent erosive dental changes [32]. Hence 9\% Etidronic acid was used in our study.

Moreover, it was reported that Saline showed irregular smear layer formation along the root surface [33]. Furthermore, much research had been carried out in this regard [34-48].

\section{Conclusion}

According to the results of the present study there is no significant difference between 17\% EDTA, 9\% Etidronic Acid in the ability to remove smear layer. Therefore, 9\% Etidronic Acid may be an appropriate alternative for EDTA as desmearing agent. All irrigation solutions have their limits and the search for an ideal root canal irrigant continues.

\section{References}

[1]. Vertucci FJ. Root canal anatomy of the human permanent teeth. Oral Surgery, Oral Medicine, Oral Pathology and Oral Radiology. 1984 Nov 1;58(5):589-99.

[2]. Alavi, A. M., Opasanon, A., Ng, Y. L., \& Gulabivala, K. Root and canal morphology of Thai maxillary molars. Int Endod J.2002; 35(5): 478-485.

[3]. Yoshida M, Fukushima H, Yamamoto K, Ogawa K, Toda T, Sagawa H. Correlation between clinical symptoms and microorganisms isolated from root canals of teeth with periapical pathosis. J Endod. 1987 Jan;13(1):24-8.Pubmed PMID: 3469298.

[4]. McComb D, Smith DC. A preliminary scanning electron microscopic study of root canals after endodontic procedures. J Endod. 1975 Jul;1(7):238-42. Pubmed PMID: 1061799.

[5]. Lester, K. S. Scanning Electron Microscopy Of Instrumented, Irrigated And 
Filled Root Canals. Br Dent J.1977;143: 359-67.

[6]. Yamada RS, Armas A, Goldman M, Lin PS. A scanning electron microscopic comparison of a high volume final flush with several irrigating solutions: Part 3. J Endod. 1983 Apr;9(4):137-42.Pubmed PMID: 6406635.

[7]. Brännström M, Nyborg H. Cavity treatment with a microbicidal fluoride solution: growth of bacteria and effect on the pulp. J Prosthet Dent. 1973 Sep;30(3):303-10.Pubmed PMID: 4516434

[8]. Economides N, Liolios E, Kolokuris I, Beltes P. Long-term evaluation of the influence of smear layer removal on the sealing ability of different sealers. J Endod. 1999 Feb;25(2):123-5.Pubmed PMID: 10204470.

[9]. Kennedy WA, Walker WA, Gough RW. Smear layer removal effects on apical leakage. Journal of Endodontics. 1986 Jan 1;12(1):21-7.

[10]. Saunders WP, Saunders EM. The effect of smear layer upon the coronal leakage of gutta-percha fillings and a glass ionomer sealer. Int Endod J. 1992 Sep;25(5):245-9.Pubmed PMID: 1291521.

[11]. Hülsmann M, Peters OA, Dummer PM. Mechanical preparation of root canals: shaping goals, techniques and means. Endod Topics. 2005 Mar; 10(1):30-76

[12]. Rotstein I, Dankner E, Goldman A, Heling I, Stabholz A, Zalkind M. Histochemical analysis of dental hard tissues following bleaching. J Endod. 1996 Jan;22(1):23-5.Pubmed PMID: 8618081.

[13]. Hülsmann M, Heckendorff M, Lennon A. Chelating agents in root canal treatment: mode of action and indications for their use. Int Endod J. 2003 Dec;36(12):810-30. PMID: 14641420.

[14]. Neelakantan P, Varughese AA, Sharma S, Subbarao CV, Zehnder M, De-Deus $\mathrm{G}$. Continuous chelation irrigation improves the adhesion of epoxy resinbased root canal sealer to root dentine. Int Endod J. 2012 Dec;45(12):1097102.Pubmed PMID: 22612994.

[15]. Zehnder M. Root canal irrigants. J Endod. 2006 May 1;32(5):389-98.

[16]. Becker, T. D., \& Woollard, G. W. Endodontic irrigation. Gen Dent.2001; 49(3):272

[17]. Carson KR, Goodell GG, McClanahan SB. Comparison of the antimicrobial activity of six irrigants on primary endodontic pathogens. J Endod. 2005 Jun;31(6):471-3.Pubmed PMID: 15917691.

[18]. Clegg MS, Vertucci FJ, Walker C, Belanger M, Britto LR. The effect of exposure to irrigant solutions on apical dentin biofilms in vitro. J Endod. 2006 May;32(5):434-7.Pubmed PMID: 16631843.

[19]. Garberoglio R, Becce C. Smear layer removal by root canal irrigants: a comparative scanning electron microscopic study. Oral Surg Oral Med Oral Pathol. 1994 Sep 1;78(3):359-67.

[20]. Ayad MF. Effects of rotary instrumentation and different etchants on removal of smear layer on human dentin. J Prosthet Dent. 2001 Jan;85(1):67-72. Pubmed PMID: 11174681.

[21]. Zehnder M, Schicht O, Sener B, Schmidlin P. Reducing surface tension in endodontic chelator solutions has no effect on their ability to remove calcium from instrumented root canals. J Endod. 2005 Aug;31(8):590-2. Pubmed PMID: 16044042.

[22]. Paul ML, Mazumdar D, Niyogi A, Baranwal AK. Comparative evaluation of the efficacy of different irrigants including MTAD under SEM. J Conserv Dent. 2013 Jul;16(4):336-41.Pubmed PMID: 23956537.

[23]. Lottanti S, Gautschi H, Sener B, Zehnder M. Effects of ethylenediaminetetraacetic, etidronic and peracetic acid irrigation on human root dentine and the smear layer. Int Endod J. 2009 Apr;42(4):335-43.Pubmed PMID: 19220516.

[24]. Grande NM, Plotino G, Falanga A, Pomponi M, Somma F. Interaction between EDTA and sodium hypochlorite: a nuclear magnetic resonance analysis. J Endod. 2006 May;32(5):460-4.Pubmed PMID: 16631849.

[25]. Cobankara FK, Erdogan H, Hamurcu M. Effects of chelating agents on the mineral content of root canal dentin. Oral Surg Oral Med Oral Pathol Oral Radiol Endod. 2011 Dec 1;112(6):e149-54.

[26]. Russell RG, Rogers MJ. Bisphosphonates: from the laboratory to the clinic and back again. Bone. 1999 Jul;25(1):97-106.Pubmed PMID: 10423031.

[27]. Weber CD, McClanahan SB, Miller GA, Diener-West M, Johnson JD. The effect of passive ultrasonic activation of $2 \%$ chlorhexidine or $5.25 \%$ sodium hypochlorite irrigant on residual antimicrobial activity in root canals. J Endod. 2003 Sep 1;29(9):562-4

[28]. Haapasalo, M., Shen, Y., Qian, W., \& Gao, Y. Irrigation in endodontics. Dent Clin North Am.2010; 54(2): 291-312.

[29]. Niyas FM, Subbarao C. Effectiveness of Sodium Hypochlorite and Etidronic
Acid in Combination as a Root Canal Irrigant with Varying Apical Preparation Sizes-An in vitro Analysis. J. Pharm. Sci. \& Res. 2017 May 1;9(5):716.

[30]. Wu MK, Kast'áková A, Wesselink PR. Quality of cold and warm guttapercha fillings in oval canals in mandibular premolars. Int Endod J. 2001 Sep;34(6):485-91.Pubmed PMID: 11556517.

[31]. Sharma N, Shekar K, Dola B, Singh V. Effect of different irrigation regimen on smear layer removal in human root dentin an invitro study. Asian Pac. J. Health Sci. 2017 Jun 30;4(2):31-7.

[32]. Yadav HK, Tikku AP, Chandra A, Yadav RK, Patel DK. Efficacy of etidronic acid, BioPure MTAD and SmearClear in removing calcium ions from the root canal: An in vitro study. Eur J Dent. 2015 Oct-Dec;9(4):523-528.Pubmed PMID: 26929691.

[33]. Aleo JJ, De Renzis FA, Farber PA, Varboncoeur AP. The presence and biologic activity of cementum-bound endotoxin. J Periodontol. 1974 Sep;45(9):6725.Pubmed PMID: 4529435.

[34]. Rajendran R, Kunjusankaran RN, Sandhya R, Anilkumar A, Santhosh R, Patil SR. Comparative Evaluation of Remineralizing Potential of a Paste Containing Bioactive Glass and a Topical Cream Containing Casein Phosphopeptide-Amorphous Calcium Phosphate: An in Vitro Study. Pesqui. Bras. Odontopediatria Clín. Integr. 2019;19.

[35]. Nandakumar M, Nasim I. Comparative evaluation of grape seed and cranberry extracts in preventing enamel erosion: An optical emission spectrometric analysis. J Conserv Dent. 2018 Sep-Oct;21(5):516-520.Pubmed PMID: 30294113.

[36]. Rajakeerthi R, Ms N. Natural Product as the Storage medium for an avulsed tooth-A Systematic Review. Cumhuriyet Dent J. 2019;22(2):249-56.

[37]. Manohar MP, Sharma S. A survey of the knowledge, attitude, and awareness about the principal choice of intracanal medicaments among the general dental practitioners and nonendodontic specialists. Indian J Dent Res. 2018 Nov 1;29(6):716.

[38]. Siddique R, Sureshbabu NM, Somasundaram J, Jacob B, Selvam D. Qualitative and quantitative analysis of precipitate formation following interaction of chlorhexidine with sodium hypochlorite, neem, and tulsi. J Conserv Dent. 2019 Jan-Feb;22(1):40-47.Pubmed PMID: 30820081.

[39]. Teja KV, Ramesh S, Priya V. Regulation of matrix metalloproteinase-3 gene expression in inflammation: A molecular study. J Conserv Dent. 2018 Nov;21(6):592.

[40]. Azeem RA, Sureshbabu NM. Clinical performance of direct versus indirect composite restorations in posterior teeth: A systematic review. J Consery Dent. 2018 Jan-Feb;21(1):2-9.Pubmed PMID: 29628639.

[41]. Poorni S, Srinivasan MR, Nivedhitha MS. Probiotic Streptococcus strains in caries prevention: A systematic review. J Conserv Dent. 2019 MarApr;22(2):123-128.Pubmed PMID: 31142979.

[42]. Jenarthanan S, Subbarao C. Comparative evaluation of the efficacy of diclofenac sodium administered using different delivery routes in the management of endodontic pain: A randomized controlled clinical trial. J Conserv Dent. 2018 May;21(3):297.

[43]. Malli Sureshbabu N, Selvarasu K, V JK, Nandakumar M, Selvam D. Concentrated Growth Factors as an Ingenious Biomaterial in Regeneration of Bony Defects after Periapical Surgery: A Report of Two Cases. Case Rep Dent. 2019 Jan 22. Pubmed PMID: 30805222.

[44]. Govindaraju L, Neelakantan P, Gutmann JL. Effect of root canal irrigating solutions on the compressive strength of tricalcium silicate cements. Clin Oral Investig. 2017 Mar;21(2):567-571.Pubmed PMID: 27469101.

[45]. Khandelwal A, Palanivelu A. Correlation between dental caries and salivary albumin in adult population in Chennai: An in vivo study. Braz. Dent. Sci. 2019 Apr 30;22(2):228-33.

[46]. Ramarao S, Sathyanarayanan U. CRA Grid - A preliminary development and calibration of a paper-based objectivization of caries risk assessment in undergraduate dental education. J Conserv Dent. 2019 Mar-Apr;22(2):185-190. Pubmed PMID: 31142991.

[47]. Siddique R, Nivedhitha MS. Effectiveness of rotary and reciprocating systems on microbial reduction: A systematic review. J Conserv Dent. 2019 Mar-Apr;22(2):114-122.Pubmed PMID: 31142978

[48]. Janani K, Sandhya R. A survey on skills for cone beam computed tomography interpretation among endodontists for endodontic treatment procedure. Indian J Dent Res. 2019 Nov-Dec;30(6):834-838.Pubmed PMID: 31939356. 